\title{
A Conceptual Engagement Framework for Gamified E- Learning Platform Activities
}

\author{
https://doi.org/10.3991/ijet.v15i22.15443
}

\author{
Mohammed Abdulaziz Alsubhi ${ }^{(凶)}$, Noraidah Sahari, \\ Tengku Siti Meriam Tengku Wook \\ Universiti Kebangsaan Malaysia, Bangi, Malaysia \\ P91209@siswa.ukm.edu.my
}

\begin{abstract}
University students utilize e-learning resources to gain access to information and to make general enquiries. Such online environments offer alternatives to traditional learning, which is now considered expensive, and time-consuming with varying results. Student disengagement is reported as the main problem for higher education e-learning platforms. E-learning developers employ Gamification to counteract this issue. A plethora of game elements are used in the gamification of e-learning. On the other hand, there are various learning activities used in e-learning platforms. Based on a literature-based analysis, this study thus identifies several game elements suitable for inclusion in learning activities in e-learning platforms to improve student engagement. This identified the most commonly used game elements, and a subsequent questionnaire survey examined real user perspectives on these elements. As a result, a conceptual engagement framework outlining how game elements might be used to support elearning activities to engage students is proposed. The framework is intended to be used as a guideline for developers and academics seeking to build engaging elearning systems based on good foundational concepts. The paper thus presents a short review of existing e-learning gamification frameworks and the steps taken towards the identification of commonly used game elements. Learning activities and student engagement factors usually employed in e-learning platforms are subsequently discussed in relation to the development of the proposed conceptual engagement framework for gamified e-learning activities.
\end{abstract}

Keywords - e-learning; activities; gamification; game elements; engagement

\section{$1 \quad$ Introduction}

Gamification is the term used for the introduction of game elements in non-game contexts and applications [1]. Gamification is usually applied in learning contexts to improve student engagement and performance [2,3]. To expedite and create continuous learning practices, modern higher education institutions have generally adopted multiple different technologies. Among these, e-learning systems are the most common [4, 5], and Cloud computing based e-learning in particular has experienced significant growth in the last decade [6-8]. However, according to the literature, the issue of student 
disengagement and boredom has arisen with regard to e-learning systems $[9,10]$. Gamification has thus been proposed as a solution to re-engaging students in e-learning systems [11-13]. Gamifying e-learning systems involves systematically adding game elements to various areas of e-learning platforms [14, 15]. An ongoing effort is thus underway to develop or identify strategies to more successfully gamify e-learning platforms [16]. Based on the literature, some researchers have already tried to develop guidelines for this process of gamifying e-learning platforms [17-19], yet the practice of gamifying e-learning platforms has varying rates of success [20]. There is a lack of an agreed-upon formal process of proven design support in the literature [20], indicating a need for the development of a formal guide or standard to streamline the gamification of e-learning platforms [21]. The research community has shown great interest in this domain, and a wide array of guidelines have emerged in the literature [22]. However, all of the guidelines appear to employ game elements for the gamification of e-learning platforms in an ad hoc manner [23, 24]. The wide variety of e-learning tools available, such as Moodle, Adapted, etc., also exacerbates this issue [21, 23, 25]. The need for an engagement framework that can be used by developers or university communities for the development of an engaging e-learning platform is clear [26]. The effort a student exerts in terms of accessing the learning process in a specific course is known as student engagement [2, 27], and the lack of face-to-face learning makes it difficult to evaluate the level of student engagement in e-learning based classes [28]. Overall, however, 78\% of students fail to complete e-learning based courses [29], which may be mainly attributed to a lack of student engagement [30]. This paper thus contributes to this field by developing an e-learning engagement framework that uses gamification in a robust manner, drawing together common elements from the literature relating to the gamification of e-learning platforms to develop a conceptual engagement framework for this process. Overall, the use of game elements including badges, points, and leader board, appears to be effective in encouraging engagement with e-learning platforms, such as in Learning Management Systems (LMSs) [31,32]. However, the success of any online environment in terms of stimulating the engagement of students needs to be confirmed by rigorous measurement [33, 34].

In this study, the idea of an engagement framework that uses gamification techniques refers to the application of specific game elements to various learning activities within an e-learning environment to solve the problem of disengagement. As such, the focus of this study is on the effectiveness and appropriateness of any application of game elements on e-learning activities. The use of these elements is then verified using qualitative and quantitative techniques. In this regard, the objectives of this study are formed as:

- Conduct literature analysis and survey to identification of common game elements that may increase student engagement in e-learning.

- Based on the result, specify learning activities such elements can be used with to increase student engagement in e-learning.

- Identify the engagement factors that can help measure how the game elements could influence student engagement. 
- Give an engagement framework that can guide developers in developing an engaging gamified e-learning system.

The rest of the paper is organised as follows: Section 2 discusses related work, while Section 3 offers the methodology. Section 4 identifies the game elements that will constitute the framework, Section 5 presents the learning activities associated with e-learning platforms, Section 6 identifies student engagement factors, and Section 7 introduces the framework itself. Section 8 thus concludes the paper.

\section{Related Work}

In higher education, gamification is used as a student engagement enhancement technique. Gamification, the employment of game elements in nongame contexts [11], has been shown to increase student engagement; hence, in a gamified e-learning system, elements are added to learning activities. Research studies on gamification of e-learning systems can be grouped into papers discussing impact on learning performance and research studies reporting on the impact of gamification on student engagement [21]. Hence, we have collected papers presenting imperial researches on the gamification of e-learning. Learning activities in e-learning systems in most cases include online-discussions, assignment submission, course assessment, and course materials. In this section, we investigate existing e-learning gamification methods and their associated outcomes. Some of the methods have their focus on improving student performance, motivation or engagement. Hence, in the related work, different methods and how they relate to the work provided in this paper are discussed.

\subsection{Researches related to student performance}

There are several frameworks orthogonal to the current work in the literature. These utilise several strategies to add elements into e-learning activities. For instance, in [17], the researchers proposed a framework offering directions to the implementation of gamification and Web 2.0 technology into e-learning systems. However, different from our work, the framework only employs badges as an element for an improved student engagement. According to the literature using badges alone as elements may have negative impacts on engagement. The researchers in [35] contributed an architecture of a gamified learning management system by creating an extensive list of game elements, as proposed by [36]. The researchers identified the requirements and introduced how different game elements would correspond to components of e-learning systems. The research did not study the impact the elements may have on student engagement which happens to be the main concern of our work. In [37], a gamification framework, that aims at increasing student motivation, is proposed. The framework adds elements to both the structure and content of e-learning systems. The research employs self-determination theory [38], a well-known human motivation theory, for the development of the framework. Likewise, in [12], a number of game elements that might fit in e-learn- 
ing platforms are investigated. The elements include points, badges, trophies, customisation, leader board, levels, progress bars, challenges, feedback, social engagement loops, and freedom to fail. The result showed an improved student performance. The researches provided reviewed in this sub-section focus mainly on investigating the impact gamification may have on student performance when employed in e-learning platforms. Our work, rather, studies student engagement in relation to gamified e-learning platforms. The game elements that may have impact on the emotional, behavioural and cognitive engagement of students are investigated in this paper. Researches related to student engagement

In [39], a conceptual model that may be used for gamifying e-learning platforms to improve student engagement was proposed. Several elements commonly used in gamifying e-learning systems were used in the research. However, the researchers did not investigate whether the model succeeded in improving student engagement. A Similar work in [40] introduced another gamified e-learning design model. In this work, the researchers presented an empirical study that investigated how the model could be used in building a gamified e-learning platform to promote student engagement. A selected group of students were exposed to the gamified e-learning, and data was subsequently collected based on the experience of the students and how they felt about the systems. Nevertheless, the researchers have mentioned a need for testing whether the model could be used in gamifying other existing e-learning systems. In other words, the model is not generic in the sense that it cannot be used in other e-learning systems for an improved student engagement. In [41], the researchers discussed the use of social networks in a gamified undergraduate course. They investigated the influence this might have on student learning achievement and developed a socially gamified learning environment that improved undergraduate student engagement. Even though the research studied student engagement in relation to gamification, it does not involve gamification of e-learning system. In [42], the researchers mapped game elements to LMSs to improve student engagement. The main purpose of the study was to identify any drawbacks gamification may have on education. They gamified an e-learning platform. The evaluation initially demonstrated that the gamified environment evidentially improved student learning engagement. The study reported in [43] also shows that a gamified online environment improves student engagement and motivation. However, the researchers did not identify which specific game elements can improve student engagement in which learning activities in the e-learning systems. Likewise, in [44], the influence of student engagement with the use of a gamified online discussion system is studied. The study has revealed that the gamification approach positively affects student engagement, though they also identified that factors such as technical issues and classmate behaviour were more likely to encourage or impede students in engaging in gamified online discussion systems. Zainuddin et al. studied the effect of gamified e-assessment on student engagement and learning performance [45]. The researches here studied the influence gamification may have one particular learning activities such as discussion and assessment respectively. That is, learning activities such as assignment and learning material are not studied in the researches. The gamification methods developed for the different e-learning strategies reviewed in this section are presented in Table 1 for clarity. 
Table 1. Summary of Reviewed Frameworks

\begin{tabular}{|c|c|c|c|c|}
\hline Source ID & Source & Game Elements & Outcome & LMS tool \\
\hline$[17]$ & $\begin{array}{l}\text { (Wongso et } \\
\text { al., 2014) }\end{array}$ & Badges & $\begin{array}{l}\text { Improved } \\
\text { Engagement }\end{array}$ & Moodle \\
\hline$[37]$ & $\begin{array}{l}\text { (Lamprinou \& } \\
\text { Paraskeva, } \\
\text { 2015) }\end{array}$ & $\begin{array}{l}\text { Achievements, points, levels, quests, teams, } \\
\text { content unlocking, progress bars, leader boards, } \\
\text { badges, boss fights, challenges, competition, co- } \\
\text { operation, feedback, rewards, win state, con- } \\
\text { straints, emotions, narrative, progression, and } \\
\text { relationships }\end{array}$ & $\begin{array}{l}\text { Improved } \\
\text { motivation and } \\
\text { performance }\end{array}$ & Moodle \\
\hline [12] & $\begin{array}{l}\text { (Strmečki et } \\
\text { al., 2015) }\end{array}$ & $\begin{array}{l}\text { Points, badges, customization, leader boards, } \\
\text { levels, challenge, quest, feedback, and freedom } \\
\text { to fail }\end{array}$ & $\begin{array}{l}\text { Improved } \\
\text { motivation and } \\
\text { engagement }\end{array}$ & Moodle \\
\hline [39] & $\begin{array}{l}\text { (Klock et al., } \\
2015)\end{array}$ & $\begin{array}{l}\text { Points, badges, levels, ranking, message board, } \\
\text { challenges, and rules }\end{array}$ & $\begin{array}{l}\text { Improved } \\
\text { motivation and } \\
\text { engagement }\end{array}$ & $\begin{array}{l}\text { Adapt- } \\
\text { Web }\end{array}$ \\
\hline [42] & $\begin{array}{l}\text { (Vanduhe et } \\
\text { al., 2018) }\end{array}$ & $\begin{array}{l}\text { Points, badges, rules, levels, leader board, and } \\
\text { progress, }\end{array}$ & $\begin{array}{l}\text { Improved } \\
\text { performance }\end{array}$ & Moodle \\
\hline$[40]$ & $\begin{array}{l}\text { (Malas \& } \\
\text { Hamtini, } \\
\text { 2016) }\end{array}$ & $\begin{array}{l}\text { Badges, leader board, Storyline, backslash, chal- } \\
\text { lenges, sharing via Facebook, points, and levels, }\end{array}$ & $\begin{array}{l}\text { Improved motiva- } \\
\text { tion and engage- } \\
\text { ment }\end{array}$ & $\begin{array}{l}\text { Open- } \\
\text { source }\end{array}$ \\
\hline [46] & $\begin{array}{l}\text { (Elabnody et } \\
\text { al., 2017) }\end{array}$ & Chart, points, badges, leader board, and levels & $\begin{array}{l}\text { Improved learning } \\
\text { outcome }\end{array}$ & $\mathrm{N} / \mathrm{A}$ \\
\hline$[47]$ & $\begin{array}{l}\text { (Katsigianna- } \\
\text { kis \& Karagi- } \\
\text { annidis, 2017) }\end{array}$ & Badges & $\begin{array}{l}\text { Improved motiva- } \\
\text { tion and engage- } \\
\text { ment }\end{array}$ & Moodle \\
\hline [41] & $\begin{array}{l}\text { (De-Marcos et } \\
\text { al., 2016) }\end{array}$ & $\begin{array}{l}\text { Points, challenges, likes, social features, and } \\
\text { communication channels }\end{array}$ & $\begin{array}{l}\text { Improved perfor- } \\
\text { mance }\end{array}$ & $\mathrm{N} / \mathrm{A}$ \\
\hline [43] & $\begin{array}{l}\text { (Ozhan et al., } \\
2020)\end{array}$ & $\begin{array}{l}\text { teams, gifting, collections, achievements, points, } \\
\text { content-unlocking, boss fight, level, and surprise }\end{array}$ & $\begin{array}{l}\text { Improved perfor- } \\
\text { mance }\end{array}$ & $\begin{array}{l}\text { Word } \\
\text { press }\end{array}$ \\
\hline$[44]$ & $\begin{array}{l}\text { (Ding, L., Er, } \\
\text { E., and Orey, } \\
\text { M. 2018) } \\
\end{array}$ & $\begin{array}{l}\text { Badges, experience points, leader board, pro- } \\
\text { gress bar, and rewards }\end{array}$ & $\begin{array}{l}\text { Improved Engage- } \\
\text { ment }\end{array}$ & gEcholu \\
\hline [48] & $\begin{array}{l}\text { (Mack et al., } \\
\text { 2019) }\end{array}$ & Points, leader board, levels, and module division & $\begin{array}{l}\text { Improved Engage- } \\
\text { ment }\end{array}$ & $\mathrm{N} / \mathrm{A}$ \\
\hline$[45]$ & $\begin{array}{l}\text { (Zainuddin, } \\
\text { Z., et al., } \\
2020)\end{array}$ & $\begin{array}{l}\text { Points, badges, avatar, Themes, music, and } \\
\text { leader boards }\end{array}$ & $\begin{array}{l}\text { Improved Engage- } \\
\text { ment }\end{array}$ & \begin{tabular}{|l|} 
Socrative, \\
Quizizz, \\
and \\
iSpring
\end{tabular} \\
\hline
\end{tabular}

\section{Methodology}

To accomplish the objectives of the research, a design science research method was adopted, as proposed in [49]. The framework is developed in five phases: problem explication, requirement identification, design and development, demonstration, and evaluation. The Explicate Problem activity is about investigating and analyzing a practical problem. The problem needs to be precisely formulated and justified by showing that it is significant for some practice. The problem should be of general interest, i.e. significant not only for one local practice but also for some global practice. Furthermore, underlying causes to the problem may be identified and analyzed. The problem explication phase of this research was discussed in the authors' previous publication $[9,50]$. 
The Requirement Identification activity outlines a solution to the explicated problem in the form of an artefact and elicits requirements, which can be seen as a transformation of the problem into demands on the proposed model. The requirements will be defined not only for functionality but also for structure and environment. Consequently, The Design and Develop activity creates an artefact that addresses the explicated problem and fulfils the defined requirements. Designing an artefact includes determining its functionality as well as its structure. In the requirement identification phase, a review of existing gamified e-learning frameworks proposed in the literature are completed to extract the game elements required for development of the framework. Once the elements are extracted, they are subsequently subjected to a real user evaluation through a questionnaire survey. Real user included higher education student from different Saudi universities (KAU, JAZAN University and TU). The students gave their thoughts on the elements whereby the elements selected in a literature analysis were reduced from 12 to 10 elements. Furthermore, the students also agreed on that the game elements would create a better student experience and better engagement. For the framework design and development, the identified game elements were mapped to four key learning activities in a way that should improve student engagement with higher education e-learning platforms in a consistent and straightforward manner. The two remaining phases which includes the demonstration and evaluation of the model are part of future research.

\section{Identifying Game Elements for e-learning Systems}

Several steps were taken as part of the framework development process. This section explicitly discusses the steps taken as part of the process of identification of suitable game elements for e-learning systems. In the process of identifying the common game elements reported in the literature, the elements of each of the frameworks studied in Section 2 were extracted. As depicted in Table 2, the first column shows the extracted game elements. Some of the frameworks used only one game element [17, 47, 51], while others used nine or more game elements $[12,37]$. As part of the mapping, it emerged that some researchers used different terminologies for the same game elements. In light of this fact, the description given to each game element in its respective source framework was utilised for comparison instead of its title. Subsequently, the descriptions of all the game elements were compared to the different terms given to elements in the source frameworks. For instance, some use the term progress bar, while some use progression for the same purpose, with the same description. The most commonly repeated element in the first list of extracted elements is thus used in this study; for example, the new list used progress bar, which is used more frequently than progression, for the associated concept, to which both titles apply. Some frameworks also used highly generic terms such as voting, while others used separate elements such as likes, dislikes, and shares. In such instances, rather than keeping a long list of all social media feature elements, the more generic terms, such as voting, are used in Table 2. Finally, the very long list of extracted game elements was reduced to those listed in the "Game elements" column of Table 2. Attempts have been made to maintain those game 
elements with slight differences in their descriptions in the list however. Table 2 allows identification of the most common elements. At this stage of the process, the most common game elements used by the source frameworks are points, badges, dashboard, teams, leader board, content unlocking, Avatar, voting, freedom to fail, levels, progress bar, and timer.

Table 2. Mapping Game Elements to Frameworks Based onPrevious Studies

\begin{tabular}{|c|c|c|c|c|c|c|c|c|c|c|c|c|c|}
\hline \multirow{2}{*}{ Game elements } & \multicolumn{13}{|c|}{ Sources ID } \\
\hline & $S A$ & $S B$ & $S C$ & $S D$ & $S E$ & $S F$ & $S G$ & $S H$ & $S I$ & $S J$ & $S K$ & $S L$ & $S M$ \\
\hline Badges & $\checkmark$ & $\checkmark$ & $\checkmark$ & $\checkmark$ & $\checkmark$ & $\checkmark$ & $\checkmark$ & $\checkmark$ & & & $\checkmark$ & & $\checkmark$ \\
\hline Dashboard & & $\checkmark$ & & $\checkmark$ & & & & & & & & & \\
\hline Points & & $\checkmark$ & $\checkmark$ & $\checkmark$ & $\checkmark$ & $\checkmark$ & $\checkmark$ & & $\checkmark$ & $\checkmark$ & $\checkmark$ & $\checkmark$ & $\checkmark$ \\
\hline Levels & & $\checkmark$ & $\checkmark$ & $\checkmark$ & $\checkmark$ & $\checkmark$ & $\checkmark$ & & & $\checkmark$ & & $\checkmark$ & $\checkmark$ \\
\hline Avatar & & $\checkmark$ & $\checkmark$ & & & & & & & & & & $\checkmark$ \\
\hline Teams & & $\checkmark$ & & & & & & & $\checkmark$ & $\checkmark$ & & & \\
\hline \begin{tabular}{|l|} 
Content \\
unlocking \\
\end{tabular} & & $\checkmark$ & $\checkmark$ & $\checkmark$ & & $\checkmark$ & & & $\checkmark$ & $\checkmark$ & & $\checkmark$ & \\
\hline Leader board & & $\checkmark$ & $\checkmark$ & & $\checkmark$ & $\checkmark$ & $\checkmark$ & & & & $\checkmark$ & $\checkmark$ & $\checkmark$ \\
\hline Boss fights & & $\checkmark$ & & & & & & & & $\checkmark$ & & & \\
\hline Competition & & $\checkmark$ & & & & & & & & & & & \\
\hline Cooperation & & $\checkmark$ & & & & & & & & & & & \\
\hline Feedback & & $\checkmark$ & & & & & & & & & & & \\
\hline Rewards & & $\checkmark$ & & & & & & & & & $\checkmark$ & & \\
\hline Win state & & $\checkmark$ & & & & & & & & & & & $\checkmark$ \\
\hline Constraints & & $\checkmark$ & & & & & & & & & & & \\
\hline Emotions & & $\checkmark$ & & & & & & & & & & & \\
\hline Narrative & & $\checkmark$ & & & & & & & & & & & \\
\hline Progress bar & & $\checkmark$ & & & $\checkmark$ & & & & & & $\checkmark$ & & \\
\hline Relationships & & $\checkmark$ & & & & & & & & & & & \\
\hline Customization & & & $\checkmark$ & & & & & & & & & & \\
\hline Feedback & & & $\checkmark$ & & & & & & & & $\checkmark$ & & \\
\hline Freedom to fail & & & $\checkmark$ & & & $\checkmark$ & & & & & & & \\
\hline Timer & & & & $\checkmark$ & $\checkmark$ & & & & & & & & \\
\hline Storyline & & & & & & $\checkmark$ & & & & & & & \\
\hline Voting & & & & & & $\checkmark$ & & & $\checkmark$ & & & & \\
\hline Chart & & & & & & & $\checkmark$ & & & & & & \\
\hline Music & & & & & & & & & & & & & $\checkmark$ \\
\hline
\end{tabular}

As a result, in the end, the framework will be unique in the number and content of elements it uses. And after having compared against the source frameworks or model, 
the framework proposed in this research is more generic as it uses commonly used element all together. In addition, as can be seen in Table 2, none of the existing frameworks literally use such common elements in their gamification strategies. The use of such common element is expected to pave the way for our future research specifically in the implementation and evaluation of the framework. In other words, developing a totally new framework may have no impact on the domain and such works may have little or no acceptance among researchers. Hence, to obtain extra insights on the selected elements, a survey has been conducted with users. Acknowledging the importance of the preceding step, identifying the most common game elements, it is vital to not only complete mapping analysis but also to remove any subjectivity from the work. A survey was thus conducted in order to assess perspectives of real users on the selected elements. The users included university students, and the questionnaire consisted of two parts, a section gathering respondents' general information and a list of game elements as seen in the mapping analysis in Table 3 . The main reason for the use of a survey was to gain user feedback on the extracted game elements, to confirm identification of the most common and suitable game elements to be used for the development of a new elearning gamification framework. The respondents were thus required to select game elements that may increase student engagement towards e-learning platforms, and the questionnaire utilised a five-point Likert scale of strongly disagree, disagree, quiet agree, agree, and strongly agree. For each item, users were required to select the scale item that best reflected their position.

The survey resulted in the identification of ten elements as compared to the 12 elements identified during mapping. As shown in Table 3, two elements were rated as less relevant for increasing student engagement and motivation in e-learning platforms. By gathering the responses of real users, the survey thus verified that, in general, the game elements most often previously utilised in the literature are suitable for the gamification of e-learning platforms. Thus, the final game elements identified for the development of the framework were points, levels, badges, leader board, dashboards, progress bars, avatars, teams, content-unlocking, and timers. Some of the recommendations given by the users included that there should be freedom to choose the assessment level in order to increase student engagement; e-learning platforms should support different types of materials, such as video, animation etc. to avoid boredom; the use of wiki-questions would allow users to create questions among themselves in order to increase student competition and collaboration. 
Table 3. Evaluation of Game Elements Based on Engagement

\begin{tabular}{|l|c|c|c|}
\hline \multicolumn{1}{|c|}{$\begin{array}{c}\text { The following game elements increase my engagement while } \\
\text { practicing e-learning activities in (LMS). }\end{array}$} & N & Mean & Std. Deviation \\
\hline a. Points. & 30 & 4.767 & .4302 \\
\hline b. Badges/ Virtual Goods/Rewards. & 30 & 4.833 & .3790 \\
\hline c. Dashboard/Achievement \& goals & 30 & 3.900 & .4807 \\
\hline d. Profile Picture/ Avatar. & 30 & 4.800 & .4068 \\
\hline e. Teams/Groups. & 30 & 3.867 & .4342 \\
\hline f. Leader boards/ Top 10. & 30 & 4.867 & .3457 \\
\hline g. Content unlocking. & 30 & 4.067 & .6915 \\
\hline h. Voting/ likes/dislike. & 30 & 2.533 & .8193 \\
\hline i. Freedom to fail. & 30 & 2.500 & .7311 \\
\hline j. Levels/stages. & 30 & 4.600 & .4983 \\
\hline k. Progress bar. & 30 & 4.500 & .5085 \\
\hline l. Timer/ countdown. & 30 & 4.033 & .7649 \\
\hline
\end{tabular}

The main reason for the use of a survey was to gain user feedback on the extracted game elements, to confirm identification of the most common and suitable game elements to be used for the development of a new e-learning gamification framework.

\section{$5 \quad$ Learning Activities}

Higher education has changed from the former conventional classroom-based systems to various types of e-learning, thus reaching far beyond the confines of classrooms. Systems of e-learning are primarily aimed at enhancing the interactions between students and teachers with the help of technology, as exemplified by Learning Management Systems (LMSs). In this regard, an LMS can be conceived of as a tool that manages, tracks, and assesses the activities carried out by all students in a given course[5254].University students usually visit online resources to gain easy access to information and to make general enquiries. Such online environments offer an alternative to traditional learning which is considered expensive and time-consuming, producing varying results. To accomplish e-learning, universities employ a plethora of different e-learning systems [55]. LMSs allow tutors to manage every aspect of a course, permitting them to accept assignments digitally, store assessment results, and keep in touch with students [55]. Likewise, some studies [56-58] have shown that LMSs should facilitate access to learning materials and taking assessments, and should also include discussion forums to allow greater participation in the e-learning platforms. In addition, according to [59], LMSs used by most universities provide students with an environment where their assignments are submitted, course material is downloaded, where students can participate in course discussions. Many types e-learning activity are possible, but some are less frequently employed by universities. Gamifying all activities may create confusion to students or may affect their performance with regard to the e-learning platform. In this light, four learning activities are commonly covered by most studies: learning materials, assessment, assignment, and discussion activities. Learning materials activity includes all course documents submitted and distributed by teachers via the e- 
learning system. These learning materials may be in many different formats such as Word documents, PDFs, PPT slideshows, audio tracks, and videos. E-learning platforms make it easy to manage course-related material, and thus, with e-learning, access to learning materials is easier and can be done at any time. It also increases the reusability of learning materials [60, 61]. E-learning assessment activity involves all exercises created for student practice, along with the exams or quizzes conducted for knowledge testing delivered via e-learning platforms. Such assessment reduces the workload on teachers and administrative staff. E-learning also eases the processes of marking, disseminating grades, and performing quality assurance reviews of exams. Elearning assessment can be created to facilitate automated marking as well as to create a reusable repository of past exam questions and student grades $[45,62,63]$.

Assignment activity in e-learning systems allows students to submit assignments within an upload tool. E-learning platforms also provide related functionalities to manage submission and evaluation processes, including setting and communicating deadlines, allocating first assessors, providing feedback to learners, and awarding marks [64, 65]. Traditional e-learning system strategies, including online assignment modules, lack solutions to the issue of student motivation, however [45]. The discussion activity offered by e-learning platforms helps students embrace higher-order thinking, active learning, and social presence outside the classroom. It creates a place of interconnection between students, teachers, and even parents to facilitate the sharing and exchange of information [66-68]. It is believed that e-learning discussions promote high levels of cognitive engagement and critical thinking, and one of the main advantages of e-learning discussion is to create an opportunity to bring together varying viewpoints from students who come from different backgrounds [69]. Any lack of student engagement in such e-learning discussions threatens to undermine its benefits [70], and some students have repeatedly shown a lack of interest in such discussions [71]. Adding game elements may rather motivate students to participate in such discussions.

\section{Student Engagement Factors}

Previous studies conducted on student engagement in the context of gamified elearning systems have discussed a range of engagement factors. For example, to investigate how gamified e-quizzes can engage students, Zainuddin et al. discussed four factors of student engagement including behavioural, emotional, cognitive, and agentic [45], while Hew and Lo discussed only one engagement factor (cognitive) [72], and Huang, Hew, and Lo discussed two factors behavioural and cognitive [73]. In [44], the researchers employed behavioural, cognitive and emotional engagement factors to study student engagement concerning gamified online discussions, while in [74], the roles of emotional, cognitive, and behavioural aspects of student engagement in online e-learning were studied. Likewise, in [75], the researchers have used effective, behavioural, and cognitive aspects to study student engagement with gamified e-learning activities, while in another study, the researchers discussed the emotional, social, and behavioural factors underlying student engagement with a gamified e-learning platform 
$[76,77]$. The summary of the reviewed researches against the type of engagement factors are depicted in Table 4.

Table 4. Summary of researches against engagement factors

\begin{tabular}{|c|c|c|c|c|}
\hline \multirow{2}{*}{ Researches } & \multicolumn{5}{|c|}{ Engagement factors } \\
\hline & Behavioural & Emotional & Cognitive & Agentic \\
\hline$[45]$ & $\checkmark$ & $\checkmark$ & $\checkmark$ & $\checkmark$ \\
\hline$[72]$ & & & $\checkmark$ & \\
\hline$[73]$ & $\checkmark$ & & $\checkmark$ & \\
\hline$[44]$ & $\checkmark$ & $\checkmark$ & $\checkmark$ & \\
\hline$[74]$ & $\checkmark$ & $\checkmark$ & $\checkmark$ & \\
\hline$[75]$ & $\checkmark$ & $\checkmark$ & $\checkmark$ & \\
\hline$[76]$ & $\checkmark$ & $\checkmark$ & $\checkmark$ & \\
\hline
\end{tabular}

From Table 4, it is possible to deduce that most researchers employed behavioural, cognitive, and emotional or effective engagement factors in their studies. As such, this research adopted the widely accepted three-factor model as proposed in [78] and promoted in [79]. Thus, based on the research gap and the nature of the student engagement the study is interested in, the study employs behavioural, emotional, and effective as factors of engagement. Aside from the engagement factors themselves, there is a need to identify the indicators corresponding to each of the factors. Many empirical studies investigating student engagement and gamification have been conducted in e-learning, yet only few have studied indicators of engagement factors in the context of learning activities in a gamified e-learning system; further each of those has focused only on specific learning activities. In [45], the researchers investigated indicators in engagement factors of gamified e-assessment: behavioural, emotional, cognitive, and agentic, while in [75], the researchers posited that indicators of behavioural engagement include participation, persistence, and attention, while those of affective engagement include willingness, interest, enjoyment, and positive attitude, and cognitive engagement indicators include deep understanding, expertise, and problem-solving.

Based on such previous studies, the indicators shown in Table 5 are employed in this study.

Table 5. Student engagement factors and indicators

\begin{tabular}{|l|l|}
\hline \multicolumn{1}{|c|}{ Factors } & \multicolumn{1}{c|}{ Indicators } \\
\hline Behavioural & Participation, Persistence, Collaboration, Independent Learning \\
\hline Emotional & Fun, Interest, Enjoyment, Boredom, Curious \\
\hline Cognitive & Deep Understanding, Competition, Critical Thinking Skills, Problem-Solving \\
\hline
\end{tabular}




\section{Proposed Conceptual Engagement Framework for Gamifying e-learning Systems}

The main goal of this research is to develop an engagement framework to help guide developers seeking to incorporate game elements into LMS systems. The target outcome of the conceptual framework proposed in this paper is to increase student engagement with LMS systems. As previously discussed, LMS systems usually consist of learning materials, assessments, and discussion modules or learning activities. Incorporating game elements into LMS systems thus requires both directly and indirectly incorporating game elements into various different learning activities. The conceptual framework proposed is shown in Fig.1. The framework consists of three components: game elements or gamification components; learning activities; and student engagement components. Game elements, which influence learning activities, are thus grouped and subsequently mapped to the corresponding activities. Elements such as contentunlocking, timers, and levels are mapped to learning material activities, which implies that these three game elements, when incorporated in learning material modules in LMS systems increase the engagement of the student with that activity. The students may feel more engaged with doing assessments when badges and timer game elements are used in the assessment modules. Likewise, the assignment module can be made more attractive and engaging by using badges, timers, and teams-game elements. In addition to, there is a group of elements that influence all learning activities, which should thus be added at the system level. In the framework. These game elements include points, dashboards, leader board, and progress bars. Finally, the avatar game element is associated most significantly with the discussion learning activity, as depicted in the framework. The descriptions of the elements are given as follows: Points: They demonstrate the overall student achievement in relation to different learning activities (learning material, quiz, exam, assignment, and discussion forums) in e-learning systems [39]. That is, they can be obtained for carrying out tasks at the learning activities level as well as at the main system. Leader board: It is shown at the system level as a scoreboard displaying student's result based on the number of points and badges gained [12, 80]. Leader board is used in e-learning systems to engage student by making learning more interesting [45]. Dashboard: It provides fast feedback on summary of all completed and uncompleted activities. Likewise, dashboard helps students to identify their expected performance outcome by displaying the analytics of their activities taken throughout the e-learning system [81]. Progress bar: it tracks and displays how much progress a student has made in an e-learning activity. Based on the framework almost all learning activities are expected to have their specific progress bar [42, 82]. At the same time, there will be an accumulative progress bar displayed at the dashboard that shows the percent of the course completed by the student. Levels: they usually correspond to different modules or chapters of a course that composed by activities such as course material, assignment, and assessment [40]. Using levels e-learning platform Administrator can properly keep track of students and their records [78]. Content-unlocking: It corresponds level up the students proceed to certain levels whenever they complete certain predetermined requirements. For instance, unlocking the content of one chapter by finishing a preceding chapter [63].Badges: Students are awarded badges by 
completing certain activities including quizzes, assignments, or exam[17]. Badges are typical gamification element that indicates the achieved competence level of the student [83]. Timer: it is associated with quizzes and exams whereby it counts down the time duration dedicated for quizzes and exams [84]. It positively engages students in tasks. For example, if the student finishes exam in the given time frame then is awarded badges, thus make him more focused. Team: based on the framework team is associated with assignments, as teams who finish their work on time will be awarded. Team is more about assessing the collaboration and teamwork of a group of students to overcome challenges and defeat opponents [85]. Avatar: the use of avatar is to make students feel more secure for their privacy by obfuscating their identity and activities to others. In this way, students may feel more comfortable in taking more time on their elearning accounts $[86,87]$.

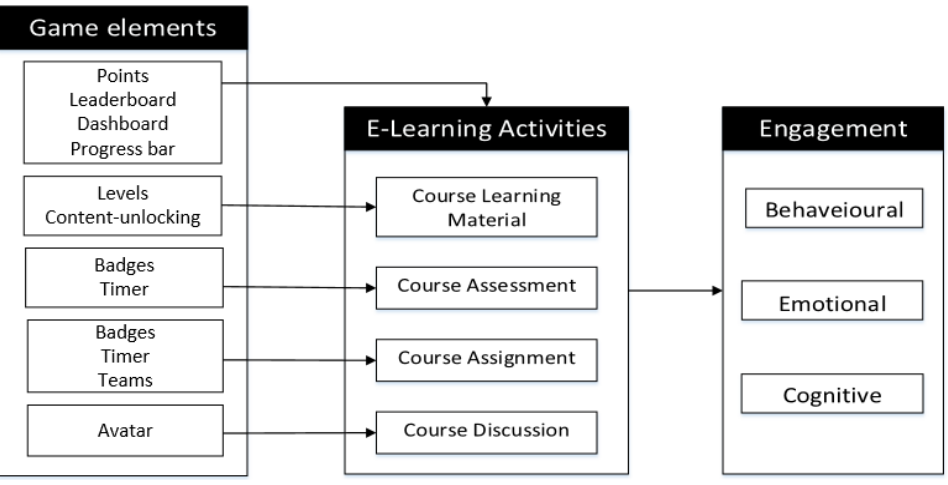

Fig. 1. Conceptual engagement framework for gamifying e-learning platform activities

\section{Conclusion}

In this paper, a conceptual framework for the gamification of e-learning systems was presented. The framework aims to guide e-learning systems developers in making informed decisions about which elements to include in specific learning modules or activities to motivate and increase user engagement. Several elements deemed suitable for the gamification of e-learning systems are thus identified in this paper, including points, levels, badges, leader board, dashboards, progress bars, avatars, teams, contentunlocking, and timers. To show which elements can be best used in which learning activities or e-learning system modules, the conceptual framework maps these various game elements to specific learning activities. In future work, the framework will be evaluated based on expert interviews with e-learning systems specialists and university professors. The research presented in this paper contributes to the research domain in essence that it is the first to investigate the impact each game element may have on the student engagement in regard to the different learning actives in e-learning systems. That is, to identify which elements may positively have an impact on which learning activity for student to be engaged in that specific activity. 


\section{Acknowledgement}

This work is supported by The Center for Software Technology and Management, Faculty of Information Science and Technology, Universiti Kebangsaan Malaysia.

\section{References}

[1] A. Rojas-López, E. G. Rincón-Flores, J. Mena, F. J. García-Peñalvo, and M. S. RamírezMontoya, "Engagement in the course of programming in higher education through the use of gamification," Universal Access in the Information Society, vol. 18, no. 3, pp. 583-597, 2019. https://doi.org/10.1007/s10209-019-00680-z

[2] S. ASHAARI, "Quantifying user experience in using learning gamification website," Journal of Theoretical and Applied Information Technology, vol. 96, no. 23, 2018.

[3] S. Papadakis and M. Kalogiannakis, "Using gamification for supporting an introductory programming course. the case of classcraft in a secondary education classroom," in Interactivity, game creation, design, learning, and innovation: Springer, 2017, pp. 366-375. https://doi.org/10.1007/978-3-319-22960-7 16

[4] R. C. Clark and R. E. Mayer, E-learning and the science of instruction: Proven guidelines for consumers and designers of multimedia learning. John Wiley \& Sons, 2016. https://doi.org/10.1002/9781119239086

[5] S. Papadakis, "Evaluating a game-development approach to teach introductory programming concepts in secondary education," International Journal of Technology Enhanced Learning, vol. 12, no. 2, pp. 127-145, 2020. https://doi.org/10.1504/ijtel.2020. 106282

[6] A. N. Moussa, N. Ithnin, and A. Zainal, "CFaaS: bilaterally agreed evidence collection," Journal of Cloud Computing, vol. 7, no. 1, p. 1, 2018. https://doi.org/10.1186/s13677-017$\underline{0102-3}$

[7] A. N. Moussa, N. Ithnin, N. Almolhis, and A. Zainal, "A Consumer-Oriented Cloud Forensic Process Model," in 2019 IEEE 10th Control and System Graduate Research Colloquium (ICSGRC), 2019, pp. 219-224: IEEE. https://doi.org/10.1109/icsgrc.2019.8837 $\underline{096}$

[8] A. Alaidi, O. Yahya, and H. Alrikabi, "Using Modern Education Technique in Wasit University," 2020.

[9] M. A. Alsubhi, N. S. Ashaari, and T. S. M. T. Wook, "The Challenge of Increasing Student Engagement in E-Learning Platforms," in 2019 International Conference on Electrical Engineering and Informatics (ICEEI), 2019, pp. 266-271: IEEE. https://doi.org/10.1109/ iceei47359.2019.8988908

[10] F. L. Khaleel, N. S. Ashaari, T. S. M. T. Wook, and A. Ismail, "Gamification-based learning framework for a programming course," in 2017 6th International Conference on Electrical Engineering and Informatics (ICEEI), 2017, pp. 1-6: IEEE. https://doi.org/10.1109/ iceei.2017.8312377

[11] S. Deterding, M. Sicart, L. Nacke, K. O'Hara, and D. Dixon, "Gamification. using gamedesign elements in non-gaming contexts," in CHI'11 extended abstracts on human factors in computing systems, 2011, pp. 2425-2428. https://doi.org/10.1145/1979742.19795 $\underline{75}$ 
[12] D. Strmečki, A. Bernik, and D. Radošević, "Gamification in e-Learning: introducing gamified design elements into e-learning systems," Journal of Computer Science, vol. 11, no. 12, pp. 1108-1117, 2015. https://doi.org/10.3844/jcssp.2015.1108.1117

[13] M. Huda et al., "Big data emerging technology: insights into innovative environment for online learning resources," vol. 13, no. 1, pp. 23-36, 2018.

[14] N. Vidakis, A. K. Barianos, A. M. Trampas, S. Papadakis, M. Kalogiannakis, and K. Vassilakis, "Generating Education in-Game Data: The Case of an Ancient Theatre Serious Game," in CSEDU (1), 2019, pp. 36-43. https://doi.org/10.5220/0007810800 $\underline{360043}$

[15] H. T. Alrikabi, A. H. M. Alaidi, A. S. Abdalrada, and F. T. J. I. J. o. E. T. i. L. Abed, "Analysis the Efficient Energy Prediction for 5G Wireless Communication Technologies," vol. 14, no. 08, pp. 23-37, 2019. https://doi.org/10.3991/ijet.v14i08.10485

[16] S. Papadakis, M. Kalogiannakis, E. Sifaki, and N. Vidakis, "Access moodle using smart mobile phones. A case study in a Greek University," in Interactivity, Game Creation, Design, Learning, and Innovation: Springer, 2017, pp. 376-385. https://doi.org/10.1007/978-3-319$\underline{76908-0 \quad 36}$

[17] O. Wongso, Y. Rosmansyah, and Y. Bandung, "Gamification framework model, based on social engagement in e-learning 2.0," in 2014 2nd International Conference on Technology, Informatics, Management, Engineering \& Environment, 2014, pp. 10-14: IEEE. https://doi.org/10.1109/time-e.2014.7011583

[18] F. L. Khaleel, N. S. Ashaari, T. S. M. T. Wook, and A. Ismail, "Methodology for developing gamification-based learning programming language framework," in 2017 6th International Conference on Electrical Engineering and Informatics (ICEEI), 2017, pp. 1-6: IEEE. https://doi.org/10.1109/iceei.2017.8312378

[19] S. Papadakis, A. M. Trampas, A. K. Barianos, M. Kalogiannakis, and N. Vidakis, "Evaluating the Learning Process: The" ThimelEdu" Educational Game Case Study," in CSEDU (2), 2020, pp. 290-298. https://doi.org/10.5220/0009379902900298

[20] A. Mora, D. Riera, C. González, and J. Arnedo-Moreno, "Gamification: a systematic review of design frameworks," Journal of Computing in Higher Education, vol. 29, no. 3, pp. 516548, 2017. https://doi.org/10.1007/s12528-017-9150-4

[21] I. Bouchrika, N. Harrati, V. Wanick, and G. Wills, "Exploring the impact of gamification on student engagement and involvement with e-learning systems," Interactive Learning Environments, pp. 1-14, 2019. https://doi.org/10.1080/10494820.2019.1623267

[22] M. A. Hassan, U. Habiba, F. Majeed, and M. Shoaib, "Adaptive gamification in e-learning based on students' learning styles," Interactive Learning Environments, pp. 1-21, 2019. https://doi.org/10.1080/10494820.2019.1588745

[23] C. Poondej and T. Lerdpornkulrat, "Gamification in e-learning," Interactive Technology and Smart Education, 2019.

[24] M. T. Alshammari, "Evaluation of Gamification in E-Learning Systems for Elementary School Students," TEM Journal, vol. 9, no. 2, pp. 806-813, 2020. https://doi.org/10. $\underline{18421 / \text { tem } 92-51}$

[25] H. T. S. ALRikabi, A. H. M. Alaidi, and F. T. J. J. o. A. R. i. D. C. S. Abed, "Attendance System Design and Implementation Based on Radio Frequency Identification (RFID) And Arduino," p.p.1342-1347,2018.

[26] R. Smiderle, S. J. Rigo, L. B. Marques, J. A. P. de Miranda Coelho, and P. A. Jaques, "The impact of gamification on students' learning, engagement and behavior based on their personality traits," Smart Learning Environments, vol. 7, no. 1, pp. 1-11, 2020. https://doi.org/10.1186/s40561-019-0098-x 
[27] H. Coates, Student engagement in campus-based and online education: University connections. Routledge, 2006.

[28] M. Hu and H. Li, "Student engagement in online learning: A review," in 2017 International Symposium on Educational Technology (ISET), 2017, pp. 39-43: IEEE. https://doi.org/10.1109/iset.2017.17

[29] O. Simpson, "22\%-can we do better?'e CWP Retention Literature Review,"” Report to the Centre for Widening Participation, Open University, 2010.

[30] J. Kuzilek, M. Hlosta, D. Herrmannova, Z. Zdrahal, and A. Wolff, "OU Analyse: analysing at-risk students at The Open University," Learning Analytics Review, pp. 1-16, 2015.

[31] R. Klemke, M. Eradze, and A. Antonaci, "The flipped MOOC: using gamification and learning analytics in MOOC design — a conceptual approach," Education Sciences, vol. 8, no. 1, p. 25,2018 . https://doi.org/10.3390/educsci8010025

[32] A. Mazarakis, "Using gamification for technology enhanced learning: The case of feedback mechanisms," Bull. IEEE Tech. Comm. Learn. Technol, vol. 17, no. 4, pp. 6-9, 2015.

[33] F. Cassano, A. Piccinno, T. Roselli, and V. Rossano, "Gamification and learning analytics to improve engagement in university courses," in International Conference in Methodologies and intelligent Systems for Techhnology Enhanced Learning, 2018, pp. 156-163: Springer. https://doi.org/10.1007/978-3-319-98872-6_19

[34] F. L. Khaleel, N. Sahari, T. S. M. T. Wook, and A. Ismail, "Gamification elements for learning applications," International Journal on Advanced Science, Engineering and Information Technology, vol. 6, no. 6, pp. 868-874, 2016. https://doi.org/10.18517/ijaseit.6. $\underline{6.1379}$

[35] J. Swacha, "An architecture of a gamified learning management system," in International Conference on Web-Based Learning, 2014, pp. 195-203: Springer.

[36] K. Werbach and D. Hunter, For the win: How game thinking can revolutionize your business. Wharton Digital Press, 2012.

[37] D. Lamprinou and F. Paraskeva, "Gamification design framework based on SDT for student motivation," in 2015 International Conference on Interactive Mobile Communication Technologies and Learning (IMCL), 2015, pp. 406-410: IEEE. https://doi.org/10. 1109/imctl.2015.7359631

[38] S.-C. Wee and W.-W. Choong, "Gamification: Predicting the effectiveness of variety game design elements to intrinsically motivate users' energy conservation behaviour," Journal of environmental management, vol. 233, pp. 97-106, 2019. https://doi.org/10.1016/j.jenvman.2018.11.127

[39] A. C. T. Klock, L. F. Da Cunha, M. F. de Carvalho, B. E. Rosa, A. J. Anton, and I. Gasparini, "Gamification in e-learning systems: A conceptual model to engage students and its application in an adaptive e-learning system," in International Conference on Learning and Collaboration Technologies, 2015, pp. 595-607: Springer. https://doi.org/10.1007/978-3-31920609-7 56

[40] R. I. Malas and T. Hamtini, "A gamified e-learning design model to promote and improve learning," Int Rev Comput Softw (IRECOS), vol. 11, pp. 8-19, 2016. https://doi.org/10. 15866/irecos.v11i1.7913

[41] L. De-Marcos et al., "Social network analysis of a gamified e-learning course: Small-world phenomenon and network metrics as predictors of academic performance," Computers in Human Behavior, vol. 60, pp. 312-321, 2016. https://doi.org/10.1016/j.chb.2016.02. $\underline{052}$

[42] V. Vanduhe et al., "Students' Evidential Increase in Learning Using Gamified Learning Environment," in Proceedings of the Future Technologies Conference, 2018, pp. 1109-1122: Springer. 
[43] Ş. Ç. Özhan and S. A. Kocadere, "The effects of flow, emotional engagement, and motivation on success in a gamified online learning environment," Journal of Educational Computing Research, vol. 57, no. 8, pp. 2006-2031, 2020. https://doi.org/10.1177/0735633 118823159

[44] L. Ding, E. Er, and M. Orey, "An exploratory study of student engagement in gamified online discussions," Computers \& Education, vol. 120, pp. 213-226, 2018. https://doi.org/10.1016/j.compedu.2018.02.007

[45] Z. Zainuddin, M. Shujahat, H. Haruna, and S. K. W. Chu, "The role of gamified e-quizzes on student learning and engagement: An interactive gamification solution for a formative assessment system," Computers \& Education, vol. 145, p. 103729, 2020. https://doi.org/10. $\underline{1016 / j . c o m p e d u .2019 .103729}$

[46] M. Elabnody, M. Fouad, F. Maghraby, and A. Hegazy, "Framework for gamification-based E-learning systems for higher education in Egypt," International Journal of Intelligent Computing and Information Sciences, vol. 17, no. 3, pp. 85-97, 2017. https://doi.org/10. $\underline{21608 / \text { ijicis.2017.19816 }}$

[47] E. Katsigiannakis and C. Karagiannidis, "Gamification and game mechanics-based e-learning: a moodle implementation and its effect on user engagement," in Research on e-Learning and ICT in Education: Springer, 2017, pp. 147-159. https://doi.org/10.1007/978-3-319$\underline{34127-9 \quad 11}$

[48] C. Mackavey and S. Cron, "Innovative strategies: Increased engagement and synthesis in online advanced practice nursing education," Nurse education today, vol. 76, pp. 85-88, 2019. https://doi.org/10.1016/j.nedt.2019.01.010

[49] P. Johannesson and E. Perjons, An introduction to design science. Springer, 2014.

[50] N. Hussien, I. Ajlan, M. M. Firdhous, and H. Alrikabi, "Smart Shopping System with RFID Technology Based on Internet of Things," 2020. https://doi.org/10.3991/ijim.v14i04. $\underline{13511}$

[51] F. L. Khaleel, N. S. Ashaari, T. S. M. T. Wook, and A. Ismail, "User-enjoyable learning environment based on Gamification elements," in 2015 International Conference on Computer, Communications, and Control Technology (I4CT), 2015, pp. 221-226: IEEE. https://doi.org/10.1109/i4ct.2015.7219570

[52] S. de Sousa Borges, V. H. Durelli, H. M. Reis, and S. Isotani, "A systematic mapping on gamification applied to education," in Proceedings of the 29th annual ACM symposium on applied computing, 2014, pp. 216-222. https://doi.org/10.1145/2554850.2554956

[53] M. A. Azmi and D. J. I. J. o. C. G. T. Singh, "Schoolcube: gamification for learning management system through microsoft sharepoint," vol. 2015, 2015. https://doi.org/10. $\underline{1155 / 2015 / 589180}$

[54] F. L. Khaleel, N. S. Ashaari, T. S. Meriam, T. Wook, and A. Ismail, "The study of gamification application architecture for programming language course," in Proceedings of the 9th international conference on ubiquitous information management and communication, 2015, pp. 1-5. https://doi.org/10.1145/2701126.2701222

[55] E. LLC, "E-learning Concepts, Trends, Applications. San Francisco, California, USA," ed, 2017.

[56] O. O. Jethro, A. M. Grace, and A. K. Thomas, "E-learning and its effects on teaching and learning in a global age," International Journal of Academic Research in Business and Social Sciences, vol. 2, no. 1, p. 203, 2012.

[57] N. Guragain, "E-learning benefits and applications," 2016.

[58] I. A. Aljazaery, H. T. S. Alrikabi, and M. R. J. i. Aziz, "Combination of Hiding and Encryption for Data Security," vol. 14, no. 9, p. 35, 2020. 
[59] B. Thoms and E. Eryilmaz, "How media choice affects learner interactions in distance learning classes," Computers \& Education, vol. 75, pp. 112-126, 2014. https://doi.org/10.1016/j.compedu.2014.02.002

[60] A. Mohammed, S. Kumar, B. M. Saleh, and A. Shuaibu, "E-learning: A tool for enhancing teaching and learning in educational institutes," International Journal of Computer Science and Information Technologies, vol. 8, no. 2, pp. 217-221, 2017.

[61] A. Uukkivi and O. Labanova, "E-learning materials, methods and tools to activate students," in New learning scenarios in digitalized world: international workshop, 2017, pp. 31-39.

[62] H. Barbosa and F. Garcia, "Importance of online assessment in the e-learning process," in 2005 6th International Conference on Information Technology Based Higher Education and Training, 2005, pp. F3B/1-F3B/6: IEEE. https://doi.org/10.1109/ithet.2005.1560 $\underline{287}$

[63] J. J. I. J. o. e. t. i. 1. Schreurs, "Total Quality Management (TQM) framework for e-learning based on EFQM and Kirkpatrick models," 2006.

[64] A. M. Quteishat, A. Al-Mofleh, M. Al-Mefleh, and M. S. Al-Batah, "Module for online assignment submission," in 2011 Fourth International Conference on Modeling, Simulation and Applied Optimization, 2011, pp. 1-6: IEEE. https://doi.org/10.1109/icmsao.2011.5775475

[65] S. Kumar Basak, M. Wotto, and P. Bélanger, "E-learning, M-learning and D-learning: Conceptual definition and comparative analysis," E-Learning and Digital Media, vol. 15, no. 4, pp. 191-216, 2018. https://doi.org/10.1177/2042753018785180

[66] L. Ding, C. Kim, and M. Orey, "Studies of student engagement in gamified online discussions," Computers \& Education, vol. 115, pp. 126-142, 2017. https://doi.org/10.1016 /j.compedu.2017.06.016

[67] A. P. Rovai, "Facilitating online discussions effectively," The Internet and Higher Education, vol. 10, no. 1, pp. 77-88, 2007. https://doi.org/10.1016/j.iheduc.2006.10.001

[68] B. Miraja, S. Persada, Y. Prasetyo, P. Belgiawan, and A. J. I. J. o. E. T. i. L. Redi, "Applying Protection Motivation Theory to Understand Generation Z Students Intention to Comply with Educational Software Anti-Piracy Law," vol. 14, no. 18, pp. 39-52, 2019. https://doi.org/10.3991/ijet.v14i18.10973

[69] N. F. M. Nor, N. A. Razak, and J. Aziz, "E-learning: Analysis of online discussion forums in promoting knowledge construction through collaborative learning," WSEAS Transactions on Communications, vol. 9, no. 1, pp. 53-62, 2010.

[70] K. F. Hew, W. S. Cheung, and C. S. L. Ng, "Student contribution in asynchronous online discussion: A review of the research and empirical exploration," Instructional science, vol. 38, no. 6, pp. 571-606, 2010. https://doi.org/10.1007/s11251-008-9087-0

[71] K. Xie, "What do the numbers say? The influence of motivation and peer feedback on students' behaviour in online discussions," British Journal of Educational Technology, vol. 44, no. 2, pp. 288-301, 2013. https://doi.org/10.1111/j.1467-8535.2012.01291.x

[72] C. K. Lo and K. F. Hew, "A comparison of flipped learning with gamification, traditional learning, and online independent study: the effects on students' mathematics achievement and cognitive engagement," Interactive Learning Environments, pp. 1-18, 2018. https://doi.org/10.1080/10494820.2018.1541910

[73] B. Huang, K. F. Hew, and C. K. Lo, "Investigating the effects of gamification-enhanced flipped learning on undergraduate students' behavioral and cognitive engagement," Interactive Learning Environments, vol. 27, no. 8, pp. 1106-1126, 2019. https://doi.org/10.1080 $\underline{10494820.2018 .1495653}$ 
[74] I. V. Osipov, E. Nikulchev, A. A. Volinsky, and A. Y. Prasikova, "Study of gamification effectiveness in online e-learning systems," International Journal of advanced computer science and applications, vol. 6, no. 2, pp. 71-77, 2015.

[75] M.-B. Ibanez, A. Di-Serio, and C. Delgado-Kloos, "Gamification for engaging computer science students in learning activities: A case study," IEEE Transactions on learning technologies, vol. 7, no. 3, pp. 291-301, 2014. https://doi.org/10.1109/tlt.2014.2329293

[76] A. DomíNguez, J. Saenz-De-Navarrete, L. De-Marcos, L. FernáNdez-Sanz, C. PagéS, and J.-J. MartíNez-Herrálz, "Gamifying learning experiences: Practical implications and outcomes," Computers \& education, vol. 63, pp. 380-392, 2013.

[77] Z. Ozcinar, V. Zakirova, R. Kurbanov, and A. J. I. J. o. E. T. i. L. Belyalova, "Analysis of the Documents Published in the Web of Science Database on Teachers' Gamification Method: A Content Analysis," vol. 14, no. 22, pp. 82-94, 2019. https://doi.org/10.3991 /ijet.v14i22.11741

[78] S. R. Jimerson, E. Campos, and J. L. Greif, "Toward an understanding of definitions and measures of school engagement and related terms," The California School Psychologist, vol. 8, no. 1, pp. 7-27, 2003. https://doi.org/10.1007/bf03340893

[79] C. Dichev and D. Dicheva, "Gamifying education: what is known, what is believed and what remains uncertain: a critical review," International journal of educational technology in higher education, vol. 14, no. 1, p. 9, 2017. https://doi.org/10.1186/s41239-017-0042-5

[80] B. Enders and K. Kapp, "Gamification, games, and learning: What managers and practitioners need to know," The e-learning Guild, 2013.

[81] S. de Freitas et al., "How to use gamified dashboards and learning analytics for providing immediate student feedback and performance tracking in higher education," in Proceedings of the 26th international conference on world wide web companion, 2017, pp. 429-434. https://doi.org/10.1145/3041021.3054175

[82] D. Kermek, D. Strmečki, M. Novak, and M. Kaniški, "Preparation of a hybrid e-learning course for gamification," in 2016 39th International Convention on Information and Communication Technology, Electronics and Microelectronics (MIPRO), 2016, pp. 829-834: IEEE. https://doi.org/10.1109/mipro.2016.7522254

[83] E. Kyewski and N. C. Krämer, "To gamify or not to gamify? An experimental field study of the influence of badges on motivation, activity, and performance in an online learning course," Computers \& Education, vol. 118, pp. 25-37, 2018. https://doi.org/10.1016 /..compedu.2017.11.006

[84] A. Matenga, T. Crow, M. Walmsley, A. Luxton-Reilly, and B. Wuensche, "Evaluation of the Implementation of a Timer in Gamified Programming Exercises," in 2018 International Conference on Learning and Teaching in Computing and Engineering (LaTICE), 2018, pp. 36-41. https://doi.org/10.1016/j.compedu.2017.11.006

[85] P. Srisomboon and N. Jeerungsuwan, "Gamification Model for Virtual Team Collaborative Learning via Cloud Technology," in The Tweifth International Conference on eLearning for Knowledge-Based Society, 2015.

[86] M. Sillaots, "Using Avatars for Course Management and Immersion," in International Conference on Games and Learning Alliance, 2014, pp. 163-173: Springer. https://doi.org/10.1007/978-3-319-22960-7_16

[87] H. M. Alakrash, N. A. Razak, and E. S. J. M. E. Bustan, "The Effectiveness of Employing Telegram Application in Teaching Vocabulary: A Quasai Experimental Study," vol. 6, no. 1, 2020. 


\section{Authors}

Mohammed Abdulaziz Alsubhi is a Ph.D. candidate at Information Science and Technology, UKM, Malaysia. He received his bachelor's degree in Computer Science at Taibah University, Saudi Arabia. Master of Computer Forensic at De Montfort University in the UK. His area of expertise is Technologies in e-learning platforms and involved in researches that related to Human-computer interaction and e-learning systems \& platforms. Email: P91209@siswa.ukm.edu.my

Noraidah Sahari is an Associate professor at Center for Software Technology and Management, Faculty of Information Science and Technology, University Kebangsaan Malaysia, 43600 Bangi, Selangor, Malaysia. 'Her research interests are on Multimedia Application, E-Learning Technology, Interaction Design and Usability. Email: nsa@ukm.edu.my

Tengku Siti Meriam Tengku Wook is an Associate. Professor Dr. at Center for Software Technology and Management Research Center, Faculty of Information Science and Technology, National University of Malaysia. Currently, she is the lecturer and head of master programme. Her field of specialization is Human-Computer Interaction that includes the multimedia application, user interaction design and usability, virtual and augmented reality and also e-learning. Email: tsmeriam@ukm.edu.my

Article submitted 2020-05-06. Resubmitted 2020-07-16. Final acceptance 2020-07-16. Final version published as submitted by the authors. 